UNTAG Law Review (ULREV)

Volume 2, Issue 1, May 2018, PP 44-56

ISSN 2549-4910 (online) \& ISSN 2579-5279 (print)

http://jurnal.untagsmg.ac.id/indeks.php/ulrev/indeks

www.fakhukum.untagsmg.ac.id

\title{
TOWARDS HARMONIZATION FROM DISPUTE RELATIONSHIP BETWEEN WORKERS AND ENTERPRISES THROUGH CASE INSPECTIONS IN THE FAST INDUSTRIAL RELATIONSHIP, FAIR AND CHEAP
}

\author{
Hono Sejati \\ Darul Ulum Islamic Center University of Semarang \\ Email : honosejati89@gmail.com
}

\begin{abstract}
The problems studied in this research are (1) Why is the examination of PHI case not yet fast, fair and cheap? (2) What are the obstacles in the examination of cases in the IRC that have not been fast, fair and cheap? (3) How is the examination of the case in PHI based on the value of fast, fair and cheap? The research method used sociological juridical approach. Technique of collecting data by interview, observation, and documentation. The results of the study concluded (1) The examination of the case in the IRC has not been fast, fair and cheap due mainly to differences in perception of Lawmakers with the parties. (2) Obstacles to the examination of a PHI case are: filing a lawsuit, longer invitation because the defendant's residence is outside the legal area of the IRC, the defendant has died, the company is not operational, the lack of control of the union administrator, (3) in PHI based on the value of fast, fair and cheap is by consensus.
\end{abstract}

Keywords: Industrial Relations Court, Value Fast, Fair and Cheap

\section{INTRODUCTION}

Industrial Relations Court Procedural Law, among others, requires the strengthening of the principle of judicial administration in civil procedure law so that it is in synergy with other organic laws such as Law no. 48 of 2009 on Judicial Power, Law no. 3 of 2009 on the Second Amendment to Law no. 14 of 1985 on the Supreme Court, Law no. 49 of 2009 concerning the General Courts and other related Laws, especially the principles of legislation, as referred to in Article 5 and 6 of Law no. 10 of 2004 on the Establishment of Laws and Regulations. 
The Design of Industrial Relief Completion Event law needs to be tailored to the needs of Information and Communication Technology (ICT) utilization. Utilization of ICT to help the main task of the court is an absolute necessity. On the other hand will broaden public access to court information. This is in line with one of the objectives of IT utilization that is improving the effectiveness and public service.

The Yogyakarta District Court is one of the judicial authorities in the general judiciary based on Law Number 8 Year 2004 with the Regency / City position, and the legal area covers the Regency / City. The Yogyakarta District Court consists of five regions: Yogyakarta, Sleman, Bantul, Kulon Progo and Wonosari. Since its inception in 2006 until in 2014, the Industrial Relations Court (PHI) in the Yogyakarta District Court handled one hundred and twenty-eight cases that entered and has been terminated. Of the hundred and twenty-eight cases, there were forty-four cases filing an appeal to the Supreme Court, twenty-four peace cases. With the number of judges from 2006 to 2010 amounting to four people in 2011 to 2015 the number to six judges all Ad-Hoc judges from the three entrepreneurs elements of the three workers, so there is no case accumulation.

The examination of case of judgment in Industrial Relations Court which has not been fast, fair and cheap hence need to do research by discussing as follows:

1. Why is the examination of cases in the Industrial Relation Court in Indonesia not yet fast, fair and cheap?

2. What are the barriers that occur in the examination of cases in Industrial Relations courts not yet fast, fair and cheap?

3. How to reconstruct a court case examination based on the value of fast, fair and cheap?

\section{RESEARCH METHODS}

This research uses sociological juridical research method is empirical law research method, that is research which refers to observation, interview and sampling real (sample) as empirical data. This study uses judgment data and interviews with Industrial Relations Court Judges and other stakeholders, mediators, administrators of Apindo, SP / SB and employees of the Yogyakarta Industrial Relations Court. This study uses a critical paradigm or a criticism paradigm (Critical Theory) and uses qualitative inductive analysis.

\section{RESULTS}

Factors influencing the examination of the Industrial Relations Court decision which has not been fast, fair and cheap is the factor of "legal substance, structural law and legal culture factor". The settlement of industrial relations disputes on the IRC has several challenges and obstacles in its implementation. 
Challenges and obstacles found in practices that are a) substance and b) procedural.

1) Substantive Obstacles

a) Calling

In Article 89 of Law no. 2 Year 2004 paragraph (1) within no later than 7 (seven) working days after the appointment of the Panel of Judges, the Chairman of the Panel of Judges must have conducted the first trial.

Forms of obstacles:

The Defendant's residence outside the jurisdiction in which the IRC is located shall be called by a delegate calling with more than 7 (seven) days. In the application of Article 89 paragraph (1) of Law no. 2 Year 2004 resulted in the Assembly having lost 7 (seven) days which could not be used for the first hearing as a result the Chief Judge set a follow-up session within a period of at least 14 (fourteen) days.

In Article 89 of Law no. 2 Year 2004 paragraph (2) the summons to appear at the hearing is lawful if delivered by a summons to the parties addressed at his residence or if his residence is not known to be communicated at his last residence.

Forms of obstacles:

The notion of a legitimate summon refers to the HIR so that the Judge holds the relation of a call which may not necessarily return to the prescribed court date, so that in the first trial the Defendant did not arrive. The judge will call again until waiting for relaas of the call back as a proper call.

Resolving obstacles to the application of Article 89 paragraphs (1) and (2):

The Judge so as not to deviate from Article 89 paragraph (1) within 7 (seven) working days after the time stipulation of the Panel of Judges keeps calling the parties to the first hearing. To anticipate the loss of time at the next call:

a. With the call of the delegation and through the Facsimile and utilizing on the telephone technology advances which are "notified" there is a trial schedule for the parties on a predetermined day and is expected to be present at the hearing although a call with the delegation is possible not yet received.

b. Pursuant to Article 89 paragraph (4) the receipt of a summons by the person who is called by himself or through another person is made with a receipt.

1) Pursuant to Article 89 paragraph (4) of this call shall be made by special registered 
letter / flash which the Judge shall hold to the return of receipt from the Post Office signed by the recipient.

2) Rishi is a receipt as required in this paragraph.

a) Completion of the lawsuit

Article 83 of Law no. 2 Year 2004 paragraph (2): "The judge is obliged to examine the contents of the lawsuit and if there is any deficiency, the judge requests the plaintiff to refine the lawsuit" Forms of obstacles:

b) Completion of the lawsuit by the Judge is deemed by the defendant to harm him because on the one hand there is no limit on the refinement of the lawsuit. And on the other hand the defendant has received the letter of lawsuit, so in the trial it often happens debatable.

Resolving obstacles to the application of Article 83:

- The Judge actively convey the message of Article 83 for the smoothness of the examination process.

- The judge in advising does not alter the substance that could harm the interests of the defendant.

c) Proxy

In Article 84 of Law Number 2 Year 2004: a lawsuit involving more than one plaintiff may be filed collectively by granting special powers.

Obstacles:

- mass layoffs without any mention of numbers and people who will inevitably hamper execution, but in practice at the beginning of the trial, together the process of refining the lawsuit will take a long time because not once immediately become perfect, so it can take time in case examination.

- In the collective lawsuit still found plaintiff data which is only a list of names and in the granting of power is still global with the mention of "Plaintiffs" without attaching a list of names of the power of attorney.

Resolving barriers to the application of Article 84:

- With the consent of the defendant, the refinement of the power of attorney runs with a time limit before proof.

- The judge actively advises the Plaintiff.

d) Inspection Event 
In Article 103 of Law no. 2 Year 2004, the Panel of Judges shall be obliged to give the decision of industrial relations settlement within no later than 50 (fifty) working days since the first session.

Forms of obstacles:

- The residence of a party outside the jurisdiction in which the IRC is located, if based on the call of the delegate causes the presence of the parties unable to meet the call properly so that it may result in case examination of more than 50 (fifty) working days from the first session.

- The call of the delegate takes at least 2 (two) weeks.

- Implement call resolution as in Article 89 paragraph (1), (2) above.

Resolving barriers to the application of Article 84:

- At the beginning of the trial Court Calender is made to be agreed on the next trial day.

- Duplicate replication stages can be skipped, since civil procedure law in general does not regulate the replication.

2) Procedural Barriers

a) Calling

In Article 89 of Law no. 2 Year 2004 paragraph (1): within no later than 7 (seven) working days after the appointment of the Panel of Judges, the Chairman of the Panel of Judges must have conducted the first trial.

Forms of obstacles:

In the call of the delegation depends on the District Court calling him.

Resolving obstacles to the application of Article 89 paragraph (1)

- The IRC coordinates with all the district courts to prioritize the IRC cases that have a time limit of examination.

- PHI is actively notifying the state courts that receive delegates with Facsimilie or telephone.

In Article 89 of Law no. 2 Year 2004 paragraph (2): the summons to appear at the hearing is done legally if delivered by a summons to the parties addressed at his residence or if his / her residence is not known to be communicated at the last residence. 
Forms of obstacles:

For the Defendant by a company that is not operational the Director and its owner have all passed away or the Director has left Indonesia or unknown his place of residence makes calling difficult.

Resolving barriers to the implementation of Article 89 of Law no. 2 Year 2004 paragraph (2):

- $\quad$ Called through the village head

- Summoned by another Director at the company

b) Proxy

Article 84 of Law no. 2 Year 2004: lawsuits involving more than one plaintiff may be filed collectively by granting special powers.

Obstacles:

- $\quad$ For the holder of the power is the Management of SP not accompanied by the Decision Letter as Management.

- $\quad$ Found SP membership not yet registered to local Disnakertrans.

Resolving barriers to the application of Article 84

- $\quad$ It is recommended to complete the Management Decree

- Complete the SP/SB member's signature

c) Completion of the Claim

Article 83 of Law no. 2 Year 2004 paragraph (2): The judge is obliged to examine the contents of the lawsuit and if there is any shortage, the judge requests the Plaintiff to complete the lawsuit.

Forms of obstacles:

The role of Panietra / Substitute Registrar in assisting the refinement of the lawsuit is deemed by the plaintiff unable to fulfill his will and the claimant is more demanding that the improvement be made with the judges.

Resolving obstacles to the application of Article 83

- At the beginning of the trial the judge gives suggestions for improvement by including the Substitute Registrar/ Substitute Registrar outside the court.

d) Inspection Event

In Article 103 of Law no. 2 Year 2004: The Panel of Judges shall be obligated to give a decision on the settlement of industrial relations within the period of at least 50 (fifty) 
working days from the first session.

Forms of obstacles:

Lack of control of SP management as a holder of a nota bene not undergraduate or not a law degree, inhibits the examination because in the process of examination the judge must actively give advice and knowledge in the law.

Resolving obstacles to the application of Article 83

- It is necessary to improve the socialization of PPHI Law and civil law law periodically.

- Socialization includes employers' organizations, SP / SB, which are administered by the Disnakertrans and PHI.

Implementation Barriers (Execution) Work Back

The panel of judges presiding over the course of industrial relations in decision-making must consider the law, existing agreements, customs and justice. When deciding an industrial relations dispute, the judges must first dig, follow and understand the legal values ? ? and sense of justice living in society so that the judge's verdict will be in accordance with the law and justice in society

Cases whose content is reinstated, usually in dismissal disputes (hereinafter referred to as layoffs). The panel of judges who presides over the trial with the termination of employment dismissal (PHK) after seeing the evidence of the agreements and the legal facts presented at the hearing, the judges decided to unfit workers to be dismissed and ordered to reinstate.

If the worker / laborer has been dismissed unilaterally by the employer and is forbidden to reenter the company, then the social workers who have been laid off for reinstatement is rather difficult or never happened again it, because the appraisal of the entrepreneur about the worker / laborer has been negative or has been assessed as a problem maker in the company. The execution of a judge's verdict which already has permanent legal force and the content of the verdict is re-employed, even though the winning party has applied for the execution to the Chairman of the Industrial Relations Court, but in reality the employer is unwilling to execute the judge's decision, appraisal from employers to workers / laborers is bad. In the future, it will be badly affected by the employers against the workers / laborers concerned.

Although in the end the entrepreneurs are willing to implement the verdict, but eventually in the end the workers / laborers who resign themselves because of social factors and association within the company was difficult to be accepted again, even considered bad by the entrepreneurs in the future is also not good for performance the workforce for the company.

The judge should also make more decisions that maximally do not complicate the parties for 
the future. In this case it is sought that the right can impose a sentence in the verdict, in which case the punishment may be executed by the losing party in the litigation because if the verdict is not punitive, the principle of the ruling can not be executed.

One example of a decision that is not condemnatory is a verdict whose rulings do not punish a certain amount of money or goods. The judge shall strive for the decision of the decision to reinstate the decision to be avoided in decision making, because if the ruling of the reemployment will be fatal to the worker / laborer in the event that the verdict is executed will obtain the social difference received by the worker / laborer when hired back in accordance with the verdict. But if it is necessary to provide a verdict in which the verdict is to be reemployed, it must also be accompanied by forced money (Dwangsom), which will be the forced money as punishment if the losing party in the litigation will not carry out its verdict. In order for a verdict whose reinstatement of hiring can be carried out voluntarily.

The judges must have done their best to solve the case of termination of employment. The judge can not refuse the case for any reason.

However the judges here are more concerned with the interests of the disputing workers. In order for the rights that will be obtained from the decision for the workers can be obtained with the maximum and also can be felt as fair as possible for all parties. According to the authors, to create justice as fair as possible and no unwanted events occurred in the execution of the judge's judgment took place, it is not desirable that the implementation of the execution took place there was also a massive demonstration conducted by the workers, which later feared would increase the risks and losses suffered by the parties. Before the execution took place it would be good to negotiate in advance to create a situation and conditions that are so that the interests of all parties can be smoothly without any obstacles. The contents of the verdict must indeed be accompanied by forced money (Dwangsom). Because if forced employers reemploy the workers, of course, will create an atmosphere that is not conducive in the employment of these workers and employers.

Through the verdict, the judge may order employers to hire workers. This means that the judge instructs the employer to commit certain legal acts, namely in the form of employing workers / laborers. If this is not exercised, then the entrepreneur has committed an act against the law, because his actions are contrary to the rights of others. The legal consequence of the form is that the employer must bear the compensation suffered by the workers.

The solution to solve the above problem, one of the most urgent is civil law reform. In the midst of the tendency of people who choose to settle disputes / disputes through the judiciary, it is important to establish a legal system through credible and up to date civil procedural law instruments. If the system or the rules of the game have been built, the merger of the ceremony 
will adjust to that system. This is intended in addition to addressing the problem of the slow settlement of cases as well as to shorten the distance between justice and seekers of justice.

The need for a national industrial relations court law is urgent and needs to be adjusted to the legal policies of the law, strengthening the role of the judiciary as one of the pillars of law enforcement in the development of national law. So re-arrange the regulation relating to judicial court implementation in order to realize the optimal duties and functions of the judiciary. This is in line with the legal reform agenda which essentially requires various improvements in the court environment, such as human resources, court administration, and infrastructure including the law of the show. We can not keep on wearing outdated colonial inheritance laws like HIR / RBg. Besides obsolescence, the law of industrial relations court is dualism, HIR applies to Java and Madura region while RBg applies outside Java, although the content is not much different.

The settlement of industrial relations disputes based on consensus principles for consensus is implemented bipartite, this mechanism must be carried out under other mechanisms. Such an out-of-court settlement mechanism puts forward the principle of deliberation to consensus.

Table 1

Examination of cases in PHI based on the value of fast, fair, and cheap

\begin{tabular}{|c|l|l|}
\hline No & \multicolumn{1}{|c|}{ Subject } & \multicolumn{1}{c|}{ Description } \\
\hline 1 & $\begin{array}{l}\text { Reconstruction } \\
\text { basic }\end{array}$ & $\begin{array}{l}\text { - Local Wisdom : the 5th principle of Pancasila. } \\
\text { - Wisdom International: implementation of employment } \\
\text { cases in various countries. }\end{array}$ \\
\hline 2 & $\begin{array}{l}\text { Reconstruction } \\
\text { paradigm }\end{array}$ & $\begin{array}{l}\text { - The reconstruction paradigm of constructing a PHI } \\
\text { case-based examination is fast, fair and cheap }\end{array}$ \\
\hline 3 & $\begin{array}{l}\text { Reconstruction } \\
\text { purpose }\end{array}$ & $\begin{array}{l}\text { - Achieve rapid, fair and inexpensive PHI case checks } \\
\text { to create harmonious relationships between employers } \\
\text { and workers }\end{array}$ \\
\hline 4 & Research Novelty & $\begin{array}{l}\text { 1.The examination of cases in the Industrial Relations } \\
\text { Court is currently not fast, fair and cheap due mainly } \\
\text { to the difference in the filing of a lawsuit whereby in } \\
\text { the provisions of civil procedure law in the case of } \\
\text { filing a lawsuit essentially in a district court in which } \\
\text { the defendant resides or is domiciled (Article 118 } \\
\text { HIR / Article 142 RBg, while in Article 81 of Law } \\
\text { No. 2 Year 2004 stipulates that industrial relations } \\
\text { dispute lawsuits in District Courts whose jurisdiction } \\
\text { covers the place where workers are employed. }\end{array}$ \\
&
\end{tabular}




\begin{tabular}{|l|l|} 
From this provision there is a Rei forum sequititrum \\
factor that has been known to be abandoned. The \\
legislator does not provide an explanation of the \\
application of the lawsuit filed in the place where \\
the worker / laborer works. \\
2. The obstacles that occur in the examination of \\
industrial relations court cases are: filing of a lawsuit, \\
longer invitation because the defendant's residence \\
outside the legal area of the IRC is present or the \\
defendant has died, the non-operational company or \\
director has left Indonesia, as well as the lack of \\
control of the Management of Trade Unions as the \\
holder of power which in fact is not a graduate or law \\
degree will hamper the examination because in the \\
process of examination the judge must actively give \\
advice and knowledge of the law. \\
3. The reconstruction of the fair value of case \\
examination in a fair, prompt and inexpensive PHI \\
aims to restore harmonization of labor relations with \\
employers through consensus deliberations at PHI \\
peace meetings. The legal reconstruction of a rapid, \\
fair and inexpensive PHI case review is: Article 89 \\
paragraph 1 of Law No. 2 Year 2004 which shall be \\
within 3 (three) working days since the establishment \\
of the judges, the chairman of the panel of judges \\
shall have conducted the first trial by calling one with \\
the SMS media, whatssapp or email, and must use \\
call relaas. Reconstruction of Article 103 of Law \\
No. 2 Year 2004 on the content of judges wajb gives \\
decision of PHI settlement within no later than \\
50 (fifty) days from the first session with added \\
shorten to 4 (four) trials: \\
(1).The plaintiff's peace and the defendant by the judge \\
(2).The reading of the lawsuit and answer the answer \\
(3).Plaintiff and defendant's proof \\
(4).Decision \\
\end{tabular}

In order to harmonize the relations of workers and employers by reconstructing the concept of case examination in the industrial relations court, it must adapt to the culture of the people in Indonesia where consensus / consensus becomes one of the methods of settlement so that just discussion is a very effective and more efficient dispute resolution method than the settlement through court. In the event of a conflict, the settlement of the dispute can be pursued peacefully, 
without prejudice to the mechanism of coercion.

This can be seen in Law no. 2 of 2004 on Industrial Relations Disputes Settlement, which affirms that the parties shall endeavor to settle disputes through bipartite negotiations before making any other efforts. Given the findings of this study, consensus deliberations between workers and employers will result in harmonization at the level of industrial relations courts supporting the theory of justice / consensus deliberation, Responsive Theory, Law Enforcement Theory, Conflict Theory, and Progressive Law Theory.

\section{CONCLUSION}

1. The examination of cases in the Industrial Relations Court is not yet fast, fair and cheap due to the difference in the filing of a lawsuit whereby in the provisions of civil procedure law in the case of filing a lawsuit essentially in a district court in which the defendant resides or is domiciled (Article $118 \mathrm{HIR}$ / Article $142 \mathrm{RBg}$, while in Article 81 of Law No. 2 Year 2004 stipulates that industrial relations dispute lawsuits in the District Courts whose jurisdiction covers the place where workers work. From these provisions there is a rei forum sequititrum factor that has been known to be abandoned. The legislator does not provide an explanation of the application of the lawsuit filed in the place where the worker / laborer works.

2. The constraints that occur in the examination of industrial relations court cases include substantive barriers and procedural barriers: filing a lawsuit, longer invocation because the defendant's residence outside the legal area of the IRC is present or the defendant has died, the company is not operational or the director has left Indonesia, and the lack of control of the union as a holder of a power of attorney who notabene not a law degree.

3. Implementation of the examination of the case at the IRC fair, fast and cheap to the harmonization of relations from labor disputes with employers through consensus in PHI peace conference. The legal reconstruction of the examination of the case in the PHI which is fast, fair and inexpensive is: Article 89 paragraph 1 of Law No. 2 Year 2004 whose contents within no later than 3 (three) working days since the establishment of the judges, the chairman of the panel of judges must have do the first trial by calling one with SMS media, whatssapp, or email, and not having to use call relay.

4. Reconstruction of Article 103 of Law No. 2 Year 2004 on the content of judges required gives decision of PHI settlement within no later than 50 (fifty) days from the first session with added shorten to 4 (four) trials:

i. Plaintiff's peace and defendant by the judge 
ii. The reading of the lawsuit and answer the answer

iii. Proof of the plaintiff and the defendant

iv. Decision

\section{REFERENCES}

\section{Books}

Ahmad Fadlil Sumadi, 2012, Hukum dan Keadilan Sosial, Materi Perkuliahan Program Doktor Ilmu Hukum Universitas Islam Sultan Agung Tanpa Penerbit, Jakarta.

Aloysius Uwiyono, 2003. Implikasi Hukum Pasar Bebas dalam Kerangka AFTA terhadap

Hukum Ketenagakerjaan di Indonesia. Jurnal Hukum Bisnis, Vol. 22, Yayasan Pengembang Hukum Bisnis, Jakarta.

Asri Wijayanti, 2009. Hukum Ketenagakerjaan Pasca Reformasi, Jakarta : Sinar Grafika.

Dedi Pahroji \& Holyness N. Singadimedja, Perbandingan Sistem Hukum Ketenagakerjaan Negara Malaysia dan Negara Indonesia dalam Perlindungan Hukum dan Penegakan Hak Asasi Manusia. Telah Dipublikasikan di Majalah Ilmiah Solusi Unsika ISSN 1412-86676 Vol. 11 No. 24 Ed. Sep-Nop. 2012.

Farid Mu'azd, 2006. Pengadilan Hubungan Industrial dan Alternatif Penyelesaian Perselisihan Hubungan Industrial di Luar Pengadilan, Jakarta.

Johny Ibrahim, 2007. Teori dan Metodologi Penelitian Hukum Normatif, Malang : Bayu Media.

Lilik Mulyadi dan Agus Subroto, 2011. Penyelesaian Perkara Pengadilan Hubungan Industrial dalam Teori dan Praktik, Bandung : Alumni.

Satjipto Rahardjo, 2007. Biarkan Hukum Mengalir (Catatan Kritis tentang Pergulatan Manusia dan Hukum), Jakarta : Kompas.

Sentosa Sembiring, 2005. Penyelesaian Perselisihan Hubungan Industrial (PPHI), Bandung : Nuansa Aulia.

Sulistyowati Irianto dan Shidarta, 2013. Metode Penelitian Hukum, Jakarta : Yayasan Pustaka Obor Indonesia.

Ugo dan Pugiyo. 2011. Hukum Acara Penyelesaian Hubungan Industrial. Jakarta.

Yessiarie Silvanny Sibot, Pelaksanaan Putusan (Eksekusi) Perkara Perselisihan Hubungan Industrial Dalam PerspektifPekerja/Buruh (Studi Kasus Di Pengadilan Perselisihan Hubungan Industrial Palangkaraya), Jurnal Penelitian, Program 
Hono Sejati : Towards Harmonization From Dispute Relationship Between Workers And .....

Studi Magister Ilmu Hukum Fakultas Hukum, Universitas Brawijaya, Malang, 2013.

\section{Interview Result :}

Deden Fine Laksana, SH, selaku Hakim PHI Yogyakarta, 16 Februari 2015.

Ibu Sumarni, SH, selaku Mediator Dinas Tenaga Kerja dan Transmigrasi Yogyakarta, tanggal 12 Februari 2015.

Sri Waryanti, SH, selaku Advokat LBH Yogyakarta, tanggal 17 Februari 2015.

Subronto, SH, MH selaku Hakim PHI Yogyakarta, 18 Februari 2015

\section{Regulation}

Undang-Undang Dasar Negara Republik Indonesia Tahun 1945

Undang-Undang No. 4 Tahun 2004 tentang Kekuasaan Kehakiman

Undang-Undang Nomor 5 Tahun 2004 tentang Perubahan Atas Undang-Undang Nomor 14 Tahun 1985 tentang Mahkamah Agung.

Undang-Undang Nomor 13 Tahun 2013 tentang Ketenagakerjaan.

Undang-Undang Nomor 2 Tahun 2004 tentang Penyelesaian Perselisian Hubungan Industrial PERMA No. 01 Tahun 2008 tentang Prosedur Mediasi di Pengadilan menggantikan PERMA No. 02 Tahun 2003 